\title{
牛乳中に含まれる自然抗体の腸内細菌叢に及ぼす影響
}

\author{
岩附 聡，木島佳子，塩野谷博 * \\ アサマ化成株式会社
}

\section{Effect of Natural Milk Antibodies on Intestinal Flora}

\author{
Satoshi Iwatsuki, Yoshiko Kijima and Hiroshi Shionoya* \\ Asama Chemical Co., Ltd., 20-3, Nihonbashi Kodenma-cho, Chuo-ku, Tokyo 103-0001
}

\begin{abstract}
The intake of antibodies in the diet is expected to improve intestinal flora and to have an effect against human pathogens, but reports in this field are scarce. We administered whey protein concentrate (WPC) that was rich in natural milk antibodies against human pathogens to healthy elderly volunteers and analyzed fecal flora by T-RFLP and FISH. T-RFLP data for the intestinal flora showed the presence of 29 bacterial operational taxonomic units (OTUs). The administration of milk antibodies for 3 weeks resulted in the reduction of OTU 369 (Clostridium cluster IV), OTU 469 (Bacteroides), and OTU 853 (Bacteroides), and the increase in OTU 366 (Bacteroides), OTU 443 (unidentified bacteria) and OTU 995 (Clostridium subcluster XIVa). Bifidobacteria and Lactobacilli were not influenced by the administration of milk antibodies. For FISH, fecal samples obtained for 8 weeks of WPC treatment were analyzed for bacterial counts by 16S rRNA hybridization. No effect was observed on number of total bacteria and Bifidobacteria were observed. However, numbers of E. coli, Clostridium difficile and C. perfringens decreased. In contrast, Lactobacilli, Bacteroides spp., Prevotella, and Bacteroides fragilis increased. Measurement of milk IgG in feces following administration of $320 \mathrm{mg}$ of bovine immunoglobulin showed that $800 \mu \mathrm{g}(0.24 \%)$ was recovered. The influence of administration of milk antibodies on intestinal bacterial flora was discussed from the aspects of endotoxin translocation and improvement of rheumatoid arthritis.
\end{abstract}

(Received Sep. 28, 2010 ; Accepted Feb. 17, 2011)

Keywords : natural milk antibodies, whey protein concentrate, intestinal microflora, bacterial toxin, translocation キーワード：ミルク抗体，乳清タンパク濃縮物，腸内細菌，エンドトキシン，トランスロケーション

ヒト腸内には 1000 種以上, 総細菌数で $1 \times 10^{14}$ 個に及ぶ 腸内細菌が常在し，その構成は個人差が大きいが個々人で 安定した状態を保っていると考えられ, 腸内細菌叢といわ れる ${ }^{1) \sim 3)}$. 正常な腸内細菌叢は健康維持に不可欠の要因で あり，そのバランスの崩壊は多くの健康障害の原因となる ことが知られている( ${ }^{4)}$. . 腸内細菌叢は健康維持増進に作 用するとされる細菌種 (ビフィズス菌, 乳酸菌など), ホス 卜の免疫低下時に病原菌としても作用する日和見細菌（大 腸菌，プロテゥス菌など）と有害菌（病原性大腸菌など） の 3 つに分類され, 一定のバランスを取りつつホストと共 存している. 腸内細菌叢に影響する要因としては薬剤占, 食事 ${ }^{5) 6)}$, ストレス ${ }^{5)}$, 遺伝形質 (白血球型, HLA ${ }^{7) 8)}$, 年 齢4)9910), 抗体 ${ }^{11) ~ 14) ~ な と ゙ か ゙ あ る . ~}$

腸内細菌叢の異常としては下痢がその代表例であるが, それに対して, ウシ初乳中に含まれる抗体, 特に消化管病 原微生物のワクチン接種をしたウシ由来の初乳, またはそ

干103-0001 東京都中央区日本橋小伝馬町 20-3

*連絡先 (Corresponding author), h.shionoya@asama-chemical.co.jp
れから得られた免疫グロブリン画分が有効であることが知 られている11). しかし, 従来のミルク抗体の腸内細菌に対 する効果は, 特定の病原微生物に対する効果や, エイズ患 者における下痢症など，特定の疾病を対象にしたものが主 であり ${ }^{11)}$ ，健康人において，腸内細菌叢全般を対象にした 研究は, 我々が知る限り見当たらない.

生乳中の免疫グロブリンは IgG が主体で，その濃度は 0.03 0.7 mg/ml である ${ }^{15)}$. チーズ製造に際して, チーズと なる固形物採取で残る水溶液が乳清で, 抗体は乳清に残存 する. 乳清より乳糖と水分を除去した乳清蛋白中に抗体は 濃縮される. 我々はミルク抗体の資源として, 乳清蛋白濃 縮物 (以下 WPC 亡略称する) に注目し, 様々な WPC 中の 抗体含量を調べると，検出限界以下から $5 \%$ 台まで分布 し, その含量の差異は抗体蛋白の熱変性が関係していると 思われた，抗体の特異性をヒト由来の 33 株の各種病原菌 に対して調べると, それらの全ての病原細菌に対する抗体 があり,さらにエンドトキシン, ブドウ球菌エンテロトキ シンなどの細菌毒素に対する抗体む含まれていた ${ }^{16)}$. 今日 
まで，我々は，特別なワクチン接種を受けないウシ由来の ミルク抗体の関節リウマチへの効果を検討し, ミルク抗体 が関節リウマチの改善に有用であることを見いだし た ${ }^{17) ~ 19)}$. 本試験ではミルク抗体の有用性をさらに明らか にするため, WPC を健康な中高年のボランティアに投与 し，腸内細菌叢に及ぼす効果を調べた。

\section{実 験 方 法}

\section{1. 自然抗体含有乳清蛋白}

ヒト病原細菌に対し，高い抗体価を含有する乳清蛋白製 品 (アサマ化成), WPC6 を用いた。 その免疫グロブリン含 有量は $3.2 \%$, ヒト由来病原菌 33 種に対する平均抗体含有 量は WPC6 の $1 \mathrm{~g}$ 中 $525.2 \mu \mathrm{g}$ の製品である ${ }^{16)}$.

\section{2. 対 象}

健康な 47 名のボランティアを対象者とした. 対象者に はヘルシンキ宣言の精神に則り, あらかじめ文書にて詳細 な試験内容の説明を行い, 試験参加への同意を文書にて得 た. 対象者には降圧剤など腸内細菌叢に特に影響しないと される医薬品を常用している者や, 納豆, ヨーグルトなど 生菌を含む食品を習慣的に用いている者む含まれるが，乳 酸菌製剤を常用する者は除外した。対象者は $10 \mathrm{~g}$ の WPC 6 を，水またはぬるま湯に懸濁し，1日 1 回摂取した。摂取 時刻は指定せず, 食前, 食間, 食後, 空腹時（起床時）な ご，各自が決めた一定の時間に摂取してもらった。摂取期 間は T-RFLP 法試験（後述）では 21 日間，FISH 法試験 （後述）では 2 週間の摂取後, 2 週間休止を 2 回繰り返し, 8 週間とした。粪便は T-RFLP 法試験では試験開始日と終 了日に採取し，FISH 法では 2 週おきに 5 回採取した。粪 便は糞便採取用プラスチック容器 K1012（アズワン）に採 取し, 冷蔵保存で 1 両日中に送付され, 分析までの期間, 冷凍状態で保存した。

T-RFLP 法による分析の対象者は 18 名で，年齢は 20〜 65 歳, 男性 11 名, 女性 7 名で, 平均年齢 $49.4 \pm 15.8$ 歳 (SD) であった，FISH 法による試験に際しては，高齢化に伴い ウエルシュ菌の増加が知られているので4), 60 代が中心に なるように対象者を選び, 対象者は年齢範囲 36〜82 歳の 29 名, 男性 17 名, 女性 12 名で, 平均年齢 $61.7 \pm 12.3$ 歳で あった．試験計画の概要を図 1 に示した。

\section{3. 腸内細菌叢の変動の解析}

腸内細菌叢の分析は T-RFLP 解析と FISH 法を用いた。

(1) T-RFLP 解析による細菌叢の分析

細菌の 16SrDNA 遺伝子は菌種により異なる約 1600 の塩 基配列の遺伝子で, 細菌の分類同定と菌数または菌量の測 定に，培養法に代わって用いられている。T-RFLP (Terminal restriction fragment length polymorphism) 解析と は,この $16 \mathrm{SrDNA}$ 遺伝子を, 蛍光標識プライマーを用い て PCR で増幅後, 制限酵素B $S$ I I で切断し, 菌種ごとに異 なる長さの標識断片を, 電気泳動により分析するあのであ る。粪便検体分析は株式会社テクノスルガ（現株式会社テ クノスルガ・ラボ, 沼津市, 静岡県) にて, Nagashima ら の方法 ${ }^{20)}$ によって実施した. 制限酵素による切断で生ずる DNA 断片の長さはOTU (Operational Taxonomic Unit (操作的分類単位)）により示した. OTUは菌種を，その OTUに拈ける電気泳動 DNA 断片の蛍光密度（ピーク面 積）はある程度菌数を反映する. OTU は $16 \mathrm{SrDNA}$ の制限 酵素断片であるので，別属の細菌が同一の長さの断片とな る場合, または電気泳動で重なる場合があり, 必ずしも単 一の菌分類を示すむのではない，そこで，結果の表現には OTU 番号とその OTU 番号が示す菌の分類群を記載した. DNA 切片の解析は ABI PRISM 310 DNA Sequencer (Applied Biosystems, CA, USA) および Gene Scan (Applied Biosystems, CA, USA）を用いて行い, 電気泳動の ピーク面積の合計を 100 とし, それに対する各 OTUのピー ク面積の割り合いを占有率として表した。

(2) FISH 法による細菌叢の分析

FISH（Fluorescence in situ hybridization）法はそれ ぞれの細菌の 16SrRNA に相補性を持つ蛍光標識プローブ を用いて, 細菌のリボソーム RNA を直接染色し, 染色さ れた菌数を顕微鏡下でカウントするもので，Ribo Technologies 社 (City, Netherlands) のキットを用い, キット添 付の方法により染色された菌数を計測した. 凍結粪便を解 凍し, 約 $0.5 \mathrm{~g}$ を正確に秤取した。これをキットに添付され た緩衝液 $4.5 \mathrm{ml}$ と径 $3 \mathrm{~mm}$ のガラスビーズを加え懸濁し, 沈殿物を除去した。 上清中に含まれる菌をホルムアルデヒ ド固定し，洗浄した。次いで，プローブを加え，菌体のリ ボソーム RNA とハイブリダイズし, 顕微鏡（オリンパス

\begin{tabular}{|c|c|c|c|c|c|c|}
\hline 分析法 & ポランティアの背景 & \multicolumn{5}{|c|}{ ミルク抗体の摄取と翼便採取 } \\
\hline \multirow{3}{*}{ T-RFLP } & 人数18名 & 0 & 1 & 2 & 3 週 & \\
\hline & (男性11名,女性7名) & & \multirow[b]{2}{*}{ 提取 } & \multirow{2}{*}{\multicolumn{2}{|c|}{ 粪便 }} & \\
\hline & 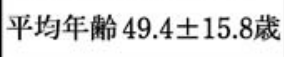 & $\begin{array}{l}\text { 翼便 } \\
\text { 採 }\end{array}$ & & & & \\
\hline \multirow{3}{*}{ FISH } & 人数 29夕 & 0 & 2 & 4 & 6 & 8 週 \\
\hline & （男性17名,女性12名) & 摂取 & \休止 & 1 捸取 & \休止 & l \\
\hline & 平均年齢 $61.7 \pm 12.3$ 歳 & 凟便 & 塤便 & 翼便 & 算便 & 糞便 \\
\hline
\end{tabular}

図 1 ミルク抗体摂取試験計画の概要 
BX41, 接眼レンズ WH15x, 対物レンズ UPlanFI100x, 蛍 光ミラーユニットNIBA および WIG）で染色された菌数 を計測した。菌数は，顕鏡視野に 20 細胞以上の場合は 10 視野につき， 20 細胞未満の場合は 20 視野につき細胞数を 計測し, 1 視野中の平均細胞数を算出した. 1 視野中の平均 細胞数が 1 未満の場合は 1 視野に 1 細胞が存在したとして 対数計算を行った. 今回の測定における検出限度は, ビ フィズス菌, 乳酸桿菌は $4 \times 10^{7}$, ウエルシュ菌は $2.6 \times 10^{6}$, ディフィシル菌は $2 \times 10^{6}$ であった。

FISH 法と T-RFLP 解析を比べると, T-RFLP 解析で は, 腸内細菌叢のうち, $0.1 \%$ 以上を占める細菌の動態を全 体的に, 手軽に解析できる特徴があるが, ウエルシュ菌な ど, 全体から見て $0.1 \%$ 以下の細菌の動態を知ることは難 しい. また， 16SrDNA の PCR 増幅産物の制限酵素断片 が, 菌種が異なっても重なって電気泳動分離される場合が あり, その場合の変動の解析が困難である.これに対し, FISH 法では，手間はかかるが，大腸菌，ウエルシュ菌な ぞ, 全体的には少数であっても選択した特定の細菌の動態 を知ることができる利点がある.

\section{4. 糞便中のウシ IgG の測定}

糞便約 $0.5 \mathrm{~g}$ を正確に秤量し, 径 $3 \mathrm{~mm}$ のガラスビーズ とキットに添付された緩衝液 $4.5 \mathrm{ml}$ を加えて懸濁後, 10000 回転で 10 分間遠心した。 その上清を無菌ろ過し，1/10 量 のウサギ血清を加え凍結保存し, ウシ IgGの測定に供し た. 抗ウシ IgG ウサギ抗体 (シバヤギ) を $0.1 \mathrm{M}$ 炭酸緩衝 液 $\mathrm{pH} 9.5$ に $25 \mu \mathrm{g} / \mathrm{ml}$ となるように希釈し，その $50 \mu 1$ を 96 穴の ELISA プレート (Nunc) のウエルに加え, $37^{\circ} \mathrm{C}$ で 1 時間コートした. ウエルを洗浄後，10\%ウサギ血清含有 リン酸緩衝液 $100 \mu 1$ を加え, $37^{\circ} \mathrm{C} 1$ 時間処理してブロック した．検体はすべて緩衝化ウサギ血清で 1 倍, 10 倍, 100 倍, 1000 倍に希釈し, その $50 \mu 1$ を各ウエルに加え, $37^{\circ} \mathrm{C}$ で 1 時間反応した。次いで, HRP 標識抗ウシ IgG ウサギ 抗体（Bethyl）を $10 \%$ ウサギ血清含有リン酸緩衝液にて 5000 倍希釈し, その $50 \mu 1$ を加え, $37^{\circ} \mathrm{C}$ で 1 時間反応した。 ELISA プレートは OPD (Sigma) を用い発色させ, マイク ロプレートリーダー（Bio-Rad, Model 550）で $490 \mathrm{~nm}$ にお ける吸光度測定し, 精製抗大腸菌 O111 LPS 抗体 ${ }^{16)}$ を標準 品とする検量線とソフト Bio-Rad, Microplate Maneger III により糞便ミルク抗体濃度を算出した。

\section{5. 統計解析}

T-RFLP 解析結果はそれぞれの OTU の占有率を\%で示 し, 各測定值と平均值士SD で示した。 ミルク抗体摂取開 始日と 21 日の 18 例の粪便中のそれぞれの占有率の変化を $\mathrm{t}$ 検定し， $p<0.05$ を有意とした.

FISH 法による分析については, 各プローブで得られた 絶対菌数を対数变換し, 個々の值とそれぞれの平均值士 SD で示した。 粪便菌数の变化はANOVAの Bonferroni correction 比較により摂取開始日に対して 2, 4, 6, 8 週後
の菌数値を検定した。ミミルク抗体のウエルシュ菌に対する 効果を, 各種解析のカテゴリーにより比較した検定は $\mathrm{t}$ 検 定によった。

\section{実 験 結 果}

\section{T-RFLP 解析による細菌叢分析結果}

PCR により増幅した腸内細菌の $16 \mathrm{~S}$ リボソーム遺伝子 の制限酵素 $B s l$ I による切断フラグメントを電気泳動分析 により，糞便中の細菌は，OTU106 から OTU990 の 29 の OTU 値を持つ細菌群に分類された.

これらの OTUについて, 18 名の対象者の占有率をミル ク抗体の 3 週間摂取前後で比較した. その結果を表 1 に示 した.

ミルク抗体の摂取は OTU124 (ビフィズス菌), OTU332； OTU517 ; OTU657 (乳酸桿菌) および OTU144; OTU317 （プレボテーラ）の占有率に対して影響は認められなかっ た. また, 占有率が有意に減少した OTUが 3 グループ, 増 加した OTU む 3 グループ見出された. 即ち, 摂取前の占 有率の割合を $100 \%$ として OTU369（クロストリジゥムク ラスターIV) が 74\% ( $p=0.0015)$, OTU469（バクテロイ デス) が $69 \%$ ( $p=0.0039)$, OTU853 (バクテロイデス) が 46\% ( $p=0.031)$ と減少した。一方, OTU955（クロストリ ジウムサブクラスターXIVa）が $119 \%(p=0.028), \mathrm{OTU}$ 366 (バクテロイデス) が $208 \%(p=0.039)$, 菌名が未定の OTU443 が 203\% ( $p=0.013)$ に増加した. 即ち, クロスト リジウム，バクテロイデスともに，ミルク抗体の損取によ り減少した OTUと増加した OTUがあった。

バクテロイデス全体（OTU366+OTU469+OTU853）と しての増減は $7.7 \%$ から $5.2 \%$ への有意な $(p=0.0045)$ 減少 であった。

\section{FISH 法による細菌叢分析結果}

T-RFLP 法による分析において，OTU469（バクテロイ デス）は腸内細菌全体の数\%を占める主要な細菌であり, この OTU が高い有意差をもって減少したことから，ミル ク抗体が腸内細菌叢に変化を及ぼすことは確実と考えられ た.しかし, 占有率の低い細菌種については, 有意な变化 であってもその確度に疑念が生ずる余地があった。また， 大腸菌の如く, 腸内細菌全体の $1 \%$ 以下の細菌数の変化は T-RFLP 法による分析では，困難であると判断された，そ こで，菌数の変化を絶対数で追える FISH 法による分析を 行った。

解析に用いたプローブは全細菌, ビフィズス菌, バクテ ロイデスとプレボテーラ, フラジリス菌, 乳酸桿菌, 大腸 菌, ウエルシュ菌, ディフィシル菌の 8 種の標識プローブ を用いて行った。

各標識プローブにより計測した対象者 29 名全員の菌数 とそれらの平均值士 SD を図 2 に示した。

糞便中の菌数の平均值を見ると, 全菌数 $\left(2.7 \times 10^{10} \sim 3.1\right.$ 
表 1 ミルク抗体の腸内細菌叢に及ぼす影響 T-RFLP 法による分析

\begin{tabular}{|c|c|c|c|c|}
\hline \multirow{2}{*}{ OTU } & \multirow{2}{*}{ 推定される菌の分類群 } & \multicolumn{2}{|c|}{ 占有率（平均\%土SD） } & \multirow{2}{*}{$p$} \\
\hline & & 摂取前 & 摂取後 & \\
\hline 106 & クロストリジウムサブクラスターXIVa & $0.25 \pm 0.49$ & $0.10 \pm 0.11$ & ns (0.098) \\
\hline 110 & $\begin{array}{l}\text { クロストリジゥムクラスターIX } \\
\text { メガモナス }\end{array}$ & $1.15 \pm 1.91$ & $0.98 \pm 1.21$ & ns \\
\hline 124 & ビフィズス菌 & $7.99 \pm 7.52$ & $7.74 \pm 6.79$ & ns \\
\hline 144 & プレボテーラ & $0.00 \pm 0.01$ & $0.00 \pm 0.00$ & ns \\
\hline 168 & クロストリジウムクラスター IV & $0.85 \pm 1.17$ & $0.42 \pm 0.64$ & ns $(0.063)$ \\
\hline 317 & プレボテーラ & $0.06 \pm 0.08$ & $0.05 \pm 0.08$ & ns \\
\hline 332 & 乳酸桿菌 & $1.49 \pm 1.26$ & $1.63 \pm 1.32$ & ns \\
\hline 338 & クロストリジウムクラスター XI & $0.71 \pm 1.16$ & $0.26 \pm 0.58$ & ns $(0.093)$ \\
\hline 366 & バクテロイデス & $0.09 \pm 0.11$ & $0.19 \pm 0.18$ & $0.039^{*}$ \\
\hline 369 & クロストリジウムクラスター IV & $3.10 \pm 3.53$ & $2.28 \pm 3.02$ & $0.0015^{* *}$ \\
\hline 423 & クロストリジウムクラスターXVIII & $0.00 \pm 0.01$ & $0.01 \pm 0.02$ & ns \\
\hline 443 & 菌名未定 & $0.12 \pm 0.16$ & $0.25 \pm 0.21$ & $0.013^{*}$ \\
\hline 469 & バクテロイデス & $6.79 \pm 4.56$ & $4.66 \pm 2.39$ & $0.0039^{* *}$ \\
\hline 494 & クロストリジウムサブクラスターXIVa & $6.89 \pm 2.92$ & $7.36 \pm 3.32$ & ns \\
\hline 505 & クロストリジウムサブクラスターXIVa & $0.63 \pm 0.02$ & $0.60 \pm 0.50$ & ns \\
\hline 514 & クロストリジウムサブクラスターXIVa & $0.53 \pm 0.45$ & $0.55 \pm 0.50$ & ns \\
\hline 517 & 乳酸桿菌 & $0.35 \pm 0.45$ & $0.35 \pm 0.57$ & ns \\
\hline 550 & 菌名未定 & $0.03 \pm 0.08$ & $0.06 \pm 0.11$ & ns \\
\hline 650 & クロストリジウムクラスターXVIII & $1.28 \pm 1.71$ & $1.11 \pm 1.75$ & ns \\
\hline 657 & 乳酸桿菌 & $5.66 \pm 9.60$ & $7.46 \pm 8.86$ & ns \\
\hline 749 & クロストリジゥムクラスター IV & $10.42 \pm 5.91$ & $10.03 \pm 7.62$ & ns \\
\hline 754 & クロストリジウムサブクラスターXIVa & $2.59 \pm 3.47$ & $3.69 \pm 4.87$ & ns \\
\hline 770 & 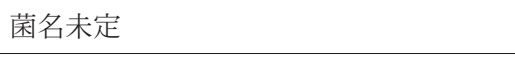 & $0.28 \pm 0.34$ & $0.47 \pm 0.60$ & ns $(0.098)$ \\
\hline 853 & バクテロイデス & $0.79 \pm 1.06$ & $0.37 \pm 0.43$ & $0.031^{*}$ \\
\hline 919 & $\begin{array}{l}\text { クロストリジウムクラスターXI } \\
\text { クロストリジウムサブクラスター XIVa }\end{array}$ & $5.75 \pm 2.69$ & $6.02 \pm 2.23$ & ns \\
\hline 940 & $\begin{array}{l}\text { クロストリジウムサブクラスターXIVa } \\
\text { エンテロバクテリウム目 }\end{array}$ & $10.07 \pm 3.91$ & $10.41 \pm 7.47$ & ns \\
\hline 955 & クロストリジウムサブクラスターXIVa & $13.63 \pm 4.67$ & $16.26 \pm 5.93$ & $0.028^{*}$ \\
\hline 968 & 菌名未定 & $1.73 \pm 1.64$ & $1.36 \pm 1.20$ & ns \\
\hline 990 & クロストリジウムサブクラスターXIVa & $16.76 \pm 5.76$ & $15.46 \pm 3.84$ & ns \\
\hline
\end{tabular}

**, $p<0.01 ; *, p<0.05$

$\times 10^{10}$ /粪便 $\left.\mathrm{g}\right)$, ビフィズス菌 $\left(2.0 \times 10^{9} \sim 3.1 \times 10^{9} / \mathrm{g}\right)$ は 8 週の検査期間を通じて一定範囲に留まり有意な変動はな かった。また，バクテロイデスとプレボテーラは 8 週にお いてのみ開始日の 1.6 倍の有意な増加 $(p<0.05)$ が認めら れた。一方，フラジリス菌（初期菌数： $4.8 \times 10^{8} / \mathrm{g}$ ）は摂取 4 週間後には 1.5 倍 $(p<0.05)$ ，さらに 8 週間後には 2.7 倍 $\left(1.2 \times 10^{9} / \mathrm{g}\right)$ と有意 $(p<0.01)$ に増加した。乳酸桿菌（初 期菌数 : $5.4 \times 10^{7} / \mathrm{g}$ ) はミルク抗体の摂取により徐々に増
加し， 8 週間後には $1.5 \times 10^{8} / \mathrm{g}$ へ之, 開始日の 3 倍弱の増 加 $(p<0.01)$ であった。

一方, 大腸菌（初期菌数 : $1.5 \times 10^{8} / \mathrm{g}$ ) はミルク抗体摂取 終了の 6 週まで有意な変化は見られなかったが， 8 週には 約半数の $8.1 \times 10^{7} / \mathrm{g}$ に減少 $(p<0.01)$ した.

ディフィシル菌は抗生物質使用後の菌交代性下痢症の原 因菌として知られる ${ }^{21)}$ 。この菌はミルク抗体摂取前では 1 例を除く 28 例 $(96.6 \%)$ において検出され（初期菌数 : 1.2 


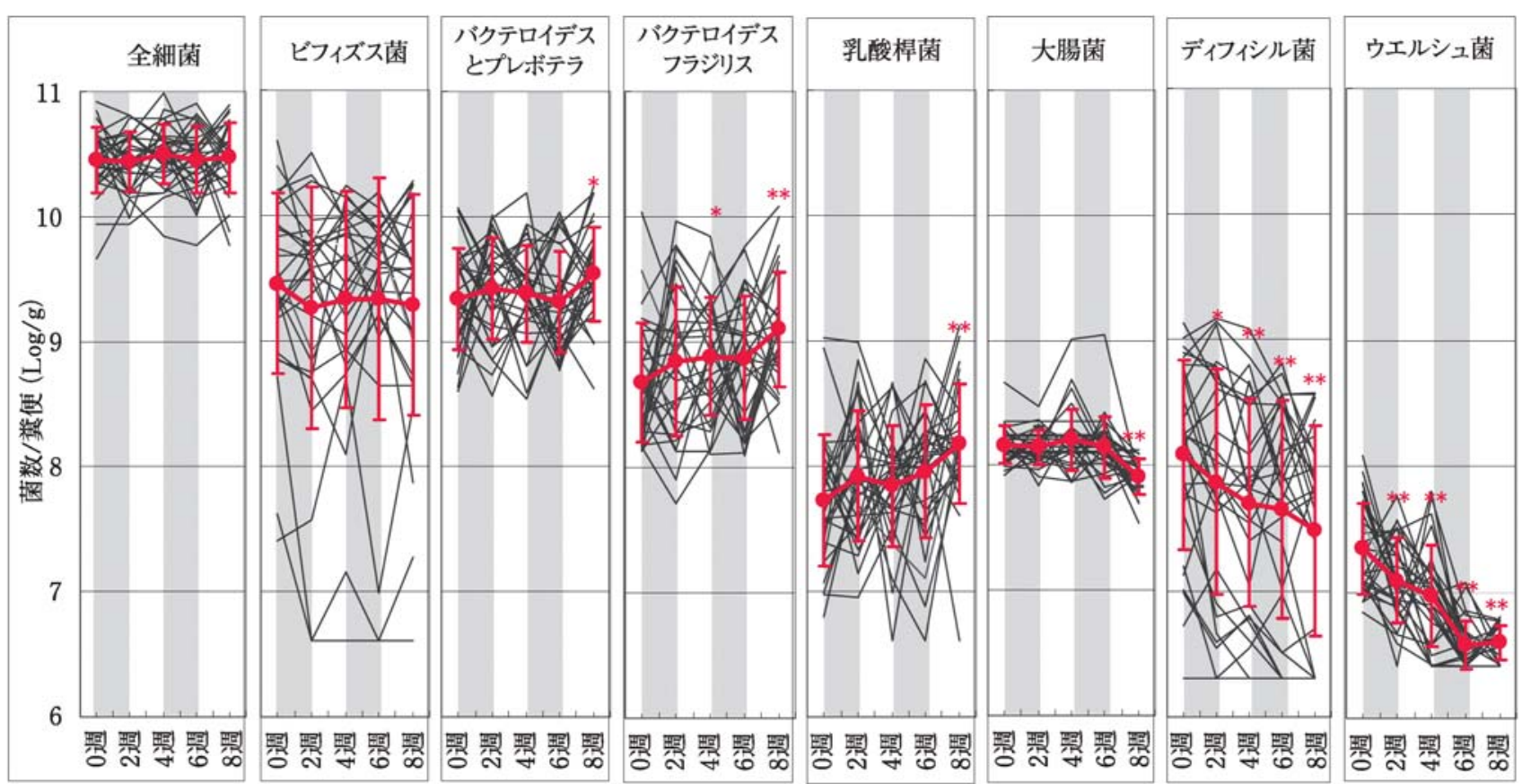

図 2 FISH 法による腸内細菌叢の分析

ミルク抗体摂取の腸内細菌に対する影響を全細菌用プローブを含む 8 プローブにより計測し，各プローブにおけ

る 29 例全例の菌数と平均士SD を示した.

*は 0 週における平均菌数と $2 ， 4 ， 6,8$ 週における ANOVA 検定を示す.

** : $p<0.01,^{*}: p<0.05$ ミルク抗体摂取 : 0 2 週, $4 \sim 6$ 週

$\left.\times 10^{8} / \mathrm{g}\right)$ たが， 2 週間のミルク抗体摂取により，有意に減 少し,さらに 8 週後には $1 / 4$ の $3.0 \times 10^{7} / \mathrm{g}$ へと減少 $(p<$ 0.01）した.

ウエルシュ菌は 29 例の全例に検出され（初期菌数 : 2.2 $\left.\times 10^{7} / \mathrm{g}\right)$, ミルク抗体摂取 2 週で有意に減少 $(p<0.01)$ し, その後屯減少が続き， 6 週， 8 週にはそれぞれ $3.8 \times 10^{6} / \mathrm{g}$, $4.0 \times 10^{6} / \mathrm{g}$ 之 $1 / 6$ 弱に減少した.

\section{3. 摂取ウシ $\operatorname{IgG}$ の䔬便への回収量}

FISH 法による試験期間中の 29 名のボランティアより, 0,2，4，6，8 週に採取した粪便中のウシ IgG の濃度（平均 $+\mathrm{SD})$ を図 3 に示した。 2 抢よび 6 週目の糞便中のウシ $\mathrm{IgG}$ 濃度はそれぞれ $2.6 \pm 2.4 \mu \mathrm{g} / \mathrm{g}$ と $2.6 \pm 2.8 \mu \mathrm{g} / \mathrm{g}$ であっ た。糞便量を平均 $300 \mathrm{~g}$ とすると, 回収されたウシ IgG は 約 $800 \mu \mathrm{g}$ であり, 摂取したウシ IgG 量 $320 \mathrm{mg}$ の 0.24\% に相当した。

ウシ抗体量の回収量をミルク抗体の食前摄取と食後摂取 で比べると, 食前摂取の $3.0 \pm 2.2 \mu \mathrm{g} / \mathrm{g}(n=11)$ に対し食後 摂取では $2.6 \pm 2.6 \mu \mathrm{g}(n=10)$ で有意な差は見られなかっ た.

4. ミルク抗体の効果に与える䔬便中ミルク抗体濃度, 年齢, 摂取タイミング, 性の影響

糞便中に回収されるミルク IgG 濃度の高低は, 消化管に おけるミルク抗体の消化分解を反映し, その結果, 腸内細 菌叢に及ぼす影響と関連すると推察される。そこで，ミル ク抗体の影響を最む受けやすいと考えられるウエルシュ菌

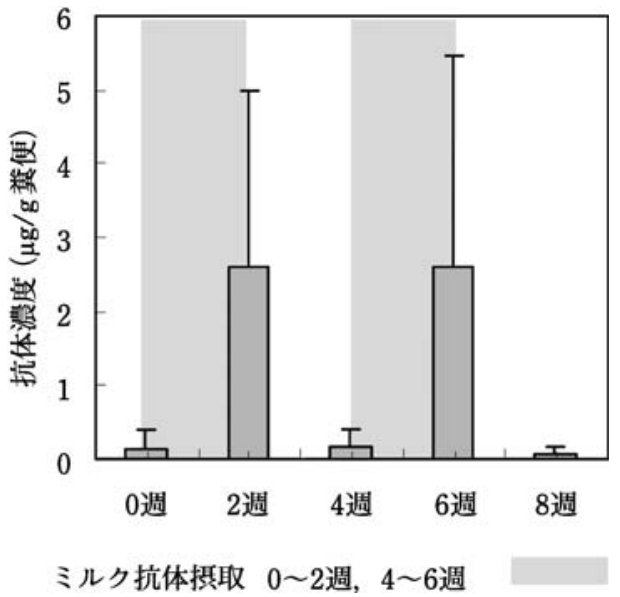

図 3 ミルク抗体の䔬便回収濃度

糞便に回収されたウシ IgG 濃度（平均値 $+\mathrm{SD}$ ）を示した.

を例にとり, 粪便中ウシ IgG 濃度が $2.6 \mu \mathrm{g} / \mathrm{g}$ 以上 $(n=$ 12) と $2.6 \mu \mathrm{g} / \mathrm{g}$ 未満 $(n=16)$ について, ウェルシュ菌の減 少効果に及ぼす影響を比べた。その結果，5回にわたる糞 便採取のいずれの時期においても菌数に有意な差は認めら なかったことから, 粪便中のミルク抗体濃度は腸内細菌に 対する影響を必ずしあ反映しないと考えられた。

ミルク抗体の作用に及ぼすその他の要因として, 年齢 65 歳以上と以下, 食前掑取と食後摂取, 性差の有無について 解析した. 結果は表 2 に示した如く, ミルク抗体の効果は, 
表 2 ミルク抗体の摂取によるウェルシュ菌に対する効果

\begin{tabular}{|c|c|c|c|c|c|c|c|c|}
\hline \multirow{2}{*}{\multicolumn{2}{|c|}{ 解析のカテゴリー }} & \multirow[b]{2}{*}{ 人数 } & \multicolumn{6}{|c|}{ ウエルシュ菌数/糞便（g） } \\
\hline & & & 摂取前 & $\%$ & 8 週経過時 & \multirow{2}{*}{$\%$} & \multirow{2}{*}{$\begin{array}{c}\begin{array}{c}p \\
\text { 摂取前 } \\
\text { 対 } \\
8 \text { 週経過時 }\end{array} \\
<0.0001\end{array}$} & \multirow{2}{*}{$\begin{array}{c}p \\
\text { 各カテゴリー内 } \\
8 \text { 週経過時の } \\
\text { 有意差の有無 }\end{array}$} \\
\hline 全 29 例 & 年齢 $61.7 \pm 12.3$ 歳 & 29 & $2.2 \times 10^{7}$ & 100 & $4.0 \times 10^{6}$ & & & \\
\hline \multirow[b]{2}{*}{ 糞便ウシ IgG 濃度 } & $2.6 \mu \mathrm{g} / \mathrm{g}$ 以上 $(4.36 \pm 2.07)$ & 12 & $2.1 \times 10^{7}$ & 100 & $3.9 \times 10^{6}$ & 18.8 & $<0.0001$ & \multirow{2}{*}{$\begin{array}{l}\text { 無し } \\
p=0.373\end{array}$} \\
\hline & $2.6 \mu \mathrm{g} / \mathrm{g}$ 未満 $(0.27 \pm 0.32)$ & 16 & $2.3 \times 10^{7}$ & 100 & $4.0 \times 10^{6}$ & 17.7 & $<0.0001$ & \\
\hline \multirow[b]{2}{*}{ 年齢 } & 66 歳以上 $71.2 \pm 3.6$ 才 & 15 & $3.0 \times 10^{7}$ & 100 & $4.2 \times 10^{6}$ & 13.8 & $<0.0001$ & \multirow{2}{*}{$\begin{array}{c}\text { 無し } \\
p=0.224\end{array}$} \\
\hline & 65 歳以下 $51.4 \pm 9.7$ 才 & 14 & $1.6 \times 10^{7}$ & 100 & $3.8 \times 10^{6}$ & 23.9 & $<0.0001$ & \\
\hline \multirow[b]{2}{*}{ 摂取時刻 } & 食前 & 11 & $2.4 \times 10^{7}$ & 100 & $3.7 \times 10^{6}$ & 15.3 & $<0.0001$ & \multirow{2}{*}{$\begin{array}{c}\text { 無し } \\
p=0.226\end{array}$} \\
\hline & 食後 & 10 & $2.0 \times 10^{7}$ & 100 & $4.2 \times 10^{6}$ & 20.7 & 0.0004 & \\
\hline \multirow[b]{2}{*}{ 性 } & 男 $66.9 \pm 8.1$ 才 & 17 & $2.8 \times 10^{7}$ & 100 & $4.2 \times 10^{6}$ & 14.9 & $<0.0001$ & \multirow{2}{*}{$\begin{array}{c}\text { 無し } \\
p=0.153\end{array}$} \\
\hline & 女 $54.3 \pm 13.6$ 才 & 12 & $1.6 \times 10^{7}$ & 100 & $3.7 \times 10^{6}$ & 23.6 & $<0.0001$ & \\
\hline
\end{tabular}

粪便中に回収されたウシ IgG 濃度, 年齢, 摂取タイミン グ，性のいずれにも影響は認められなかった。

\section{考察}

関節リウマチの動物モデルであるコラーゲン関節炎にお いて，エンドトキシンが関節炎の発症を促進 2223$)$ すること から，エンドトキシンが消化管バリヤーを通過して，体内 に移行することが関節リウマチの発症に拘わるという仮 説 ${ }^{24)}$ の元に，ミルク抗体を用いた予備的な治験を行い，一 定の効果が得られた ${ }^{17) ~ 19)}$ 。そこで, 本研究においては, ミ ルク抗体の腸内細菌叢に及ぼす影響を調べることを目的と した. その結果, T-RFLP 解析法を用いた粪便細菌の分析 により，菌の増減は，同じバクテロイデスに属する細菌種 のなかに, 増加する菌種と減少する菌種があり, 同様な現 象はクロストリジゥムでも認められた（表 1). T-RFLP 分 析では，大腸菌などの腸内細菌科の細菌は OTU940に該 当し, OTU940 はクロストリジゥムとも重なるために, 腸 内細菌科の細菌に及ぼす影響を知ることができなかった。 そこで，FISH 法により特異的なプローブを用い，大腸菌， ディフィシル菌, ウエルシュ菌のそれぞれの増減を詳しく 調べた。 これらの結果から，ミルク抗体が特定の菌の減少 および，増加に影響することが知られた。

菌の増加，減少の結果を，1）腸内細菌叢に対する効果, 2）自己免疫病との関連，3）消化管バリヤーとの関連の 3 項目に分けて，関連する文献を含めて考察する.

\section{1. 腸内細菌叢に対する効果}

免疫機構の本質が，生体防御に利する機構であるとする と, 減少した菌種は免疫機構が有害と判断した菌種, 増加 した細菌は有益と判定したという仮説が成り立つ。

ミルク抗体の摂取により増加した OTU（T-RFLP 法） および菌（FISH 法）は，OTU995（クロストリジウムサブ クラスターXIVa), OTU366 (バクテロイデス), OTU443
(菌名未定), 乳酸桿菌, フラジリス菌であった。 フラジリ ス菌はT-RFLP 解析では OTU469に含まれる（テクノス ルガ社からの私信による)。この OTU469 は全体としては 減少しているので, ミルク抗体から観て, 有益なバクテロ イデスがフラジリス菌以外にああると思われる。

バクテロイデスは大腸菌と同じくグラム陰性菌で，エン ドトキシンを有するが，大腸菌を始めとする腸内細菌科の エンドトキシンとは化学構造が異なり，毒性も 1/100～1/ 1000 である ${ }^{25)}$. しかし, IL-6 の誘導活性については大腸菌 のエンドトキシンよりあ格段に活性が強いことが報告され ている ${ }^{26)}$. T-RFLP 法ではバクテロイデスはこの主要な OTU469 が減少したために，バクテロイデス全体としては 減少であったが，FISH 法による分析では，バクテロイデ スとプレボテーラ，およびフラジリス菌は増加であった。 ミルク抗体のバクテロイデス属に及ぼす影響については, 減少の可能性が高いと思われるが，更なる検討が必要であ る。また，結果に記載したが，フラジリス菌は T-RFLP 法 ではミルク抗体により減少した OTU469 に属するので, この OTUにはフラジリス菌以外の, バクテロイデスに属 する菌で，ミルク抗体により減少した細菌を含むと考えら れる。

乳酸桿菌については，今回の試験で，T-RFLP 法解析の 3 週間，およびFISH 法による解析では 4 週では変化が見 られなかったが，8週目には 3 倍弱の有意な $(p<0.01)$ 増 加がみられた（図 2).

ビフィズス菌については，ミルク抗体の影響は認められ なかった。一方，Kushnareva ら ${ }^{12)}$ は，新生児における菌 交代症下痢症に，ウシ初乳抗体製剂を $500 \mathrm{mg} / \mathrm{kg} /$ 日の大 量投与で，粪便ビフィズス菌の増加と下痢症の改善を報告 している.

ディフィシル菌は, 今回の FISH 法による検索において 29 例中 28 例の $97 \%$ に $10^{8}$ オーダーで検出された.この結 
果は, 日本人における, 培養法による検出率が $15 \%$ 台, 菌 数が $10^{4}$ オーダーであったのと比べて著しく高かった ${ }^{21)}$.

加齢に伴い腸内細菌叢の变化, 即ち大腸菌やウエルシュ 菌の増加がある ${ }^{4) 9}$ が，これは，加齢による消化管免疫の低 下に起因するものと推察される。ミルク抗体摂取により大 腸菌やウエルシュ菌の減少が見られたことは，ミルク抗体 が老化した消化管免疫能を補った結果と見ることができる.

\section{2. 自己免疫病との関連}

関節リウマチ ${ }^{22) 23)}$, 溶血性貧血 ${ }^{27)}$ ，自己免疫性甲状腺

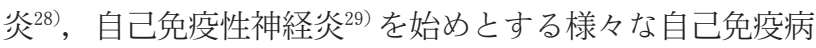
において, 消化管内のエンドトキシンその他の菌体成分 が，病気の発症に密接に関係している可能性が報告されて いる。一方, 自己免疫病の抑制要因として免疫抑制性 T リ ンパ球が挙げられる ${ }^{30)}$. したがって, 自己免疫病の治療に は，消化管内の微生物環境の制御，特にエンドトキシンレ ベルの低下と免疫抑制性 Tリンパ球の誘導, それに加え て，消化管バリヤーの健全化が重要と考えられる.

大腸菌は病原性の有無を問わずェンドトキシンを産生す る. $\mathrm{Li}$ ら $^{31)}$ は粪便中の大腸菌之血液中のエンドトキシン レベルは正の相関（ $\mathrm{r}=0.228, p<0.05)$ を示すことを報告 した，大腸菌がミルク抗体により減少するという今回の結 果は，エンドトキシンレベルの減少につながり，自己免疫 病の発症要因を抑える効果が期待できる. 抑制性 T リンパ 球の誘導については, フラジリス菌の産生する多糖体 PSA の経口投与により, 潰瘍性大腸炎モデル ${ }^{32)}$, 自己免疫 性脳脊髄炎マウス ${ }^{33)}$ において治療効果を認めた。 その機序 として，PSA の経口投与が，免疫抑制性 Tリンパ球の増 殖を促進した結果であるとした. PSA はフラジリス菌が 菌体外に産生する萊膜多糖体であり, ミルク抗体の摂取に よりフラジリス菌が 2.5 倍に増加した今回の結果は, 消化 管内における PSA の増加を伴うと思われ, ミルク抗体に よる免疫抑制性 $\mathrm{T}$ 細胞の増勢が期待できる。一方, Vaahtovuo ら ${ }^{34)}$ は関節リウマチ患者ではフラジリス菌が 有意に少ない事を報告しているので，片山 ${ }^{17)}$ 19) らによる ミルク抗体の関節リウマチ改善にはフラジリス菌の増加が 関与している可能性があり, この菌の増加と関節リウマチ の病態との関連は今後の課題である.

\section{3. 消化管バリヤーとの関連}

消化管は栄養の吸収臓器であるとと屯に, 食品や腸内細 菌などを含めた多くのしかも多量の外来物質の体内への移 行，すなわちトランスロケーションを防ぐため，物理的並 びに免疫バリヤーシステムを備えた組織である．物理的バ リヤー機構は腸管粘膜上皮細胞同士をシート状に結合させ るクローディンその他の接着タンパクにより細胞膜がお互 いに連結されて成り立っている ${ }^{35)}$.

ウエルシュ菌の産生するエンテロトキシン ${ }^{35)}$, ディフィ シル菌の産生するエンテロトキシン A およびエンテロト キシン $\mathrm{B}^{36)}$ などは消化管粘膜上皮細胞の接着タンパクに
作用してタイトジャンクションを破壊し，エンドトキシン のトランスロケーションを許す結果となる。ミルク抗体が これらの細菌毒素を産生する細菌種を減少させることは, エンドトキシンのトランスロケーションの阻止の点からむ 好ましい作用であったと考えられる.

ミルク抗体の摂取により, 乳酸桿菌については 2.8 倍の 有意な増加であった，消化管バリヤー機能の維持の観点か らみると, 乳酸桿菌はバリヤー機能を修復する作用が報告 されているので37)38)，その作用が期待できる.

バリヤーの破壊要因としては, 便秘 ${ }^{39)}$, 下痢 ${ }^{35) 36)}$, 外科手 術 ${ }^{40)}$, 精神的ストレス ${ }^{41)}$, 寒冷ストレス ${ }^{42)}$, 熱ストレス ${ }^{43)}$, 薬物 (痛み止め) ${ }^{44)}$ などがある. Khalif らは, 便秘者におい ては，粪便の乳酸桿菌，ビフィズス菌の減少と大腸菌，ブ ドウ球菌の増加とともに，消化管バリヤー機能の低下を示 した ${ }^{39)}$ 。一方，片山らは関節リウマチ患者のミルク抗体製 品「母乳のチカラ」による治験で便秘または下痢の改善に ともない関節リウマチの改善が見られたことを報告し た ${ }^{17) ~ 19)}$.これらの報告は，便秘が消化管透過性を六進する ことも伺い知れ，自己免疫疾患の病因を探るために考慮す べき要因の一つと考えられる，Bölke らは，外科手術前に ウシ初乳抗体を投与することにより，手術に伴うエンドト キシンレベルの上昇を抑えると報告した ${ }^{40)}$.

以上，ヒト病原菌に対する自然抗体を含有するミルク抗 体の摂取は，腸内細菌叢に影響した。この影響は先に行わ

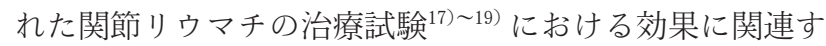
ると思われるが，今後の更なる検討が必要である.

\section{要約}

ヒト病原菌に対する抗体の摂取により，腸内細菌叢の改 善が期待できるが，その情報は乏しい，我々は，ヒト病原 菌に対するミルク由来の自然抗体を多く含む乳清蛋白を中 高年健常人ボランティアに投与し，粪便細菌叢の变化を T-RFLP 法と FISH 法により解析した。T-RFLP 法では, 腸内細菌は 29 の OTU（菌の分類群）に分けられ，ミルク 抗体の 3 週間の摂取により減少した菌は OTU369（クロス トリジゥムクラスターIV), OTU469 (バクテロイデス), OTU853 (バクテロイデス) であった。 また，増加した菌は OTU366 (バクテロイデス), OTU443 (菌名未定), OTU 995（クロストリジウムサブクラスターXIVa）で，ビフィ ズス菌, 乳酸桿菌その他には影響が見られなかった. FISH 法による解析は, ミルク抗体の影響を 8 週にわたり行っ た。全細菌数およびビフィズス菌には影響しなかった。大 腸菌, ディフィシル菌, ウエルシュ菌は減少したのに対し, バクテロイデスとプレボテーラ，フラジリス菌，乳酸桿菌 は増加した。ミルク抗体の粪便中への回収を測定すると, 摂取したミルク抗体 $320 \mathrm{mg}$ の $800 \mu \mathrm{g} \quad(0.24 \%)$ が糞便中 に回収された。ミルク抗体による腸内細菌叢への影響をエ ンドトキシンのトランスロケーション，関節リウマチの改 
善作用との関係について考察した.

\section{本研究を行うにあたり，WPCの自然抗体の研究にご協} 力いただきました女子栄養大学衛生学教室桑原祥浩教授・ 上田成子教授, 本論文の作成にご助言いただきました Chondrex Inc. 寺戸国昭博士, また, 本研究に参加してい ただいたボランティアの皆様に感謝申し上げます.

\section{文献}

1) Bäckhed, F., Ley, R.E., Sonnenburg, J.L., Daniel, A., Peterson, D.A. and Gordon, J.I., Host-bacterial mutualism in the human intestine. Science, 307, 1915-1920 (2005).

2) Tannock, G.W., Analysis of the intestinal microflora using molecular methods. Eur. J. Clin. Nutr., 56, Suppl 4, S44-S49 (2002).

3) Moore, W.E. and Holdeman, L.V., Human fecal flora : the normal flora of 20 Japanese-Hawaiians. Appl. Microbiol., 27, 961-979 (1974).

4) Mitsuoka, T., Recent trends in research on intestinal flora. Bifidobacteria Microflora, 1, 3-24, (1982).

5) Hawrelak, J.A. and Myers, S.P., The causes of intestinal dysbiosis : a review. Altern. Med. Rev., 9, 180-197 (2004).

6) Tlaskalová-Hogenová, H., Štěpánková, R., Hudcovic, T., Tučková, L., Cukrowska, B., Lodinová-Źádniková, R., Kozáková, H., Rossmann, P., Bártová, J., Sokol, D., Funda, D.P., Borovská, D., Řeháková, Z., Šinkora, J., Hofman, J., Drastich, P. and Kokešová, A., Commensal bacteria (normal microflora), mucosal immunity and chronic inflammatory and autoimmune diseases. Immunol. Lett., 93, 97-108 (2004).

7) Stewart, J.A., Chadwick, V.S. and Murray, A., Investigations into the influence of host genetics on the predominant eubacteria in the faecal microflora of children. $J$. Med. Microbiol., 54, 1239-1242 (2005).

8) Toivanen, P., Vaahtovuo, J. and Eerola, E., Influence of major histocompatibility complex on bacterial composition of fecal flora. Infect. Immun., 69, 2372-2377 (2001).

9) 光岡知足, 老化之腸内細菌, 老年消化器病， 13，85-90 (2001).

10) Hopkins, M.J., Sharp, R. and Macfarlane, G.T., Age and disease related changes in intestinal bacterial populations assessed by cell culture, $16 \mathrm{~S}$ rRNA abundance, and community cellular fatty acid profiles. Gut., 48, 198-205 (2001)

11) Korhonen, H., Marnila, P. and Gill, H.S., Bovine milk antibodies for health. Br. J. Nutr., 84, Suppl 1 : S135-S146 (2000).

12) Kushnareva, M.V., Keshishian, E.S. and Soboleva, S.V., The efficacy of using an immune lactoglobulin preparation for correcting intestinal dysbacteriosis in newborn infants. Zh. Mikrobiol. Epidemiol. Immunobiol., 2, 101-104 (1995).

13) Florén, C.H., Chinenye, S., Elfstrand, L., Hagman, C. and Ihse, I., ColoPlus, a new product based on bovine colostrums, alleviates HIV-associated diarrhoea. Scand. J. Gastroenterol., 41, 682-686 (2006).

14） Rump, J.A., Arndt, R., Arnold, A., Bendick, C., Dichtelmüller, H., Franke, M., Helm, E.B., Jäger, H., Kampmann, B. Kolb, P., Kreuz, W., Lissner, R., Meigel, W., Ostendorf, P.,
Peter, H.H., Plettenberg, A., Schedel, I., Stellbrink, H.W and Stephan, W., Treatment of diarrhoea in human immunodeficiency virus-infected patients with immunoglobulins from bovine colostrums. Clin. Investig., 70, 588-594 (1992).

15) Chen, C.C., Tu, Y.Y. and Chang, H.M., Thermal stability of bovine milk immunoglobulin $\mathrm{G}$ (IgG) and the effect of added thermal protectants on the stability. J. Food Sci., 65, 188-193 (2000).

16）木島佳子，岩附 聡，赤松裕久，寺戸国昭，桑原祥浩，上田 成子，塩野谷博，ヒト病原菌と細菌毒素に対する乳清タン パク濃縮物中の自然抗体，食科工， 56， 475-482（2009）.

17）片山 耕, 松野丈夫, 寺戸国昭, 塩野谷博, ミルク抗体の関 節リウマチ治療効果, 第 52 回日本リウマチ学会総会・学術 集会，p. 351，札幌（2008）.

18）片山 耕, 松野丈夫, 寺戸国昭, 割谷孝貴, 塩野谷博, ミル ク抗体，関節外科， 28，108-110（2009）。

19) Katayama, K., Matsuno, T., Waritani, T., Terato, K. and Shionoya, H., Supplemental treatment of rheumatoid arthritis with natural milk antibodies against enteromicrobes and their toxins : results of an open-labelled pilot study. Nutr. J., $10: 2$ (2011).

20) Nagashima, K., Hisada, T., Sato, M. and Mochizuki, J. Application of new primer-enzyme combinations to terminal restriction fragment length polymorphism profiling of bacterial populations in human feces. Appl. Environ. Microbiol., 69, 1251-1262 (2003).

21) Nakamura, S., Mikawa, M., Nakashio, S., Takabatake, M., Okado, I., Yamakawa, K., Serikawa, T., Okumura, S. and Nishida, S., Isolation of Clostridium difficile from the feces and the antibody in sera of young and elderly adults. Microbiol. Immunol., 25, 345-351 (1981).

22) Terato, K., Harper, D.S., Griffiths, M.M., Hasty, D.L., Ye, X.J., Cremer, M.A. and Seyer, J.M., Collagen-induced arthritis in mice:synergistic effect of E. coli lipopolysaccharide bypasses epitope specificity in the induction of arthritis with monoclonal antibodies to type II collagen. Autoimmunity, 22, 137-147 (1995).

23) Yoshino, S., Sasatomi, E., Mori, Y. and Sagai, M., Oral administration of lipopolysaccharide exacerbates collagen-induced arthritis in mice. J. Immunol., 163, 34173422 (1999).

24) Terato, K., Do, C.T., Comstock, B.A. and Zabrecky, J.R., A hypothesis: Two distinct factors, autoantibody to type II collagen elicited by mimic antigens and intestinal bacterial toxins, are involved independently and synergistically in the development of autoimmune arthritis. APLAR (Asia Pacific League of Associations for Rheumatology Congress) 11th : 325-328 (2004).

25) Mancuso, G., Midiri, A., Biondo, C., Beninati, C. Gambuzza, M., Macrì, D., Bellantoni, A., Weintraub, A., Espevik, T. and Teti, G., Bacteroides fragilis-derived lipopolysaccharide produces cell activation and lethal toxicity via toll-like receptor 4. Infect. Immun., 73, 56205627 (2005).

26) Takada, H., Mihara, J., Morisaki, I. and Hamada, S., Induction of interleukin-1 and -6 in human gingival fibroblast cultures stimulated with Bacteroides lipopolysaccharides. Infect. Immun., 59, 295-301 (1991).

27) Murakami, M., Nakajima, K., Yamazaki, K., Muraguchi, T., Serikawa, T. and Honjo, T., Effects of breeding environments on generation and activation of autoreactive B-1 cells in anti-red blood cell autoantibody transgenic 
mice. J. Exp. Med., 185, 791-794 (1997).

28) Penhale, W.J. and Young, P.R., The influence of the normal microbial flora on the susceptibility of rats to experimental autoimmune thyroiditis. Clin. Exp. Immunol., 72, 288-292 (1988).

29) Ochoa-Repáraz, J., Mielcarz, D.W., Ditrio, L.E., Burroughs, A.R., Foureau, D.M., Haque-Begum, S. and Kasper, L.H., Role of gut commensal microflora in the development of experimental autoimmune encephalomyelitis. $J$. Immunol., 183, 6041-6050 (2009).

30) Sakaguchi, S., Sakaguchi, N., Asano, M., Itoh. M. and Toda, M., Immunologic self-tolerance maintained by activated T cells expressing IL-2 receptor alpha-chains (CD25). Breakdown of a single mechanism of selftolerance causes various autoimmune diseases. $J$. Immunol., 155, 1151-1164 (1995).

31) Li, L., Wu, Z., Ma, W., Yu, Y. and Chen, Y., Changes in intestinal microflora in patients with chronic severe hepatitis. Chin. Med. J., 114, 869-872 (2001).

32) Round, J.L. and Mazmanian, S.K., Inducible Foxp3+ regulatory T-cell development by a commensal bacterium of the intestinal microbiota. Proc. Natl. Acad. Sci. USA., 107, 12204-12209 (2010).

33) Ochoa-Repáraz, J., Mielcarz, D.W., Wang, Y., BegumHaque, S., Dasgupta, S., Kasper, D.L. and Kasper, L.H., A polysaccharide from the human commensal Bacteroides fragilis protects against CNS demyelinating disease. Mucosal. Immunol., 3, 487-495 (2010).

34）Vaahtovuo, J., Munukka, E., Korkeamäki, M., Luukkainen, R. and Toivanen, P., Fecal microbiota in early rheumatoid arthritis. J. Rheumatol., 35, 1500-1505 (2008).

35) Sonoda, N., Furuse, M., Sasaki, H., Yonemura, S., Katahira, J., Horiguchi, Y. and Tsukita, S., Clostridium perfringens enterotoxin fragment removes specific claudins from tight junction strands: Evidence for direct involvement of claudins in tight junction barrier. J. Cell Biol., 147, 195-204 (1999).

36) Nusrat, A., von Eichel-Streiber, C., Turner, J.R., Verkade, P., Madara, J.L. and Parkos, C.A., Clostridium difficile toxins disrupt epithelial barrier function by altering membrane microdomain localization of tight junction proteins. Infect. Immun., 69, 1329-1336 (2001).

37) Gotteland, M., Cruchet, S. and Verbeke, S., Effect of Lactobacillus ingestion on the gastrointestinal mucosal barrier alterations induced by indometacin in humans. Aliment. Pharmacol. Ther., 15, 11-17 (2001).

38) Seth, A., Yan, F., Polk, D.B. and Rao, R.K., Probiotics ameliorate the hydrogen peroxide-induced epithelial barrier disruption by a PKC- and MAP kinasedependent mechanism. Am. J. Physiol. Gastrointest. Liver Physiol., 294, G1060-G1069 (2008).

39) Khalif, I.L., Quigley, E.M., Konovitch, E.A. and Maximova, I.D., Alterations in the colonic flora and intestinal permeability and evidence of immune activation in chronic constipation. Dig. Liver Dis., 37, 838-849 (2005).

40) Bölke, E., Jehle, P.M., Hausmann, F., Däubler, A., Wiedeck, H., Steinbach, G., Storck, M. and Orth, K., Preoperative oral application of immunoglobulin-enriched colostrum milk and mediator response during abdominal surgery. Shock., 17, 9-12 (2002).

41) Velin, A.K., Ericson, A.C., Braaf, Y., Wallon, C. and Söderholm, J.D., Increased antigen and bacterial uptake in follicle associated epithelium induced by chronic psychological stress in rats. Gut., 53, 494-500 (2004).

42) Anderlik, P., Szeri, I., Bános, Z. and Barna, Z., Bacterial translocation after cold stress in young and old mice. Acta. Microbiol. Hung., 37, 289-294 (1990).

43) Selkirk, G.A., McLellan, T.M., Wright, H.E. and Rhind S. G., Mild endotoxemia, NF-kappaB translocation, and cytokine increase during exertional heat stress in trained and untrained individuals. Am. J. Physiol. Regul. Integr. Comp. Physiol., 295, R611-R623 (2008).

44) Playford, R.J., MacDonald, C.E., Calnan, D.P., Floyd, D. N., Podas, T., Johnson, W., Wicks, A.C., Bashir, O. and Marchbank, T., Co-administration of the health food supplement, bovine colostrum, reduces the acute nonsteroidal anti-inflammatory drug-induced increase in intestinal permeability. Clin. Sci. (Lond.), 100, 627-633 (2001).

(平成 22 年 9 月 28 日受付，平成 23 年 2 月 17 日受理) 